\title{
The application of content analysis as a research method in management sciences ${ }^{1}$
}

\author{
Amadeusz Miązek iD \\ Poznań University of Economics and Business
}

\author{
Justyna Światowiec-Szczepańska \\ Poznań University of Economics and Business
}

\section{Introduction}

In the social world, the need for in-depth sociological analysis of messages is undeniable 2 . Management literature indicates that psychological traits play a key role in shaping the strategy and performance of firms through their impact on managerial risk taking ${ }^{3}$. Studying the effects of these traits should therefore have a high priority in management studies. However, the issue of decreasing response rates of executives impairs survey-based research ${ }^{4}$. In order to mitigate that problem, the authors attempted to answer the question: "How to study the individual characteristics of the core decision makers in firms, bearing in mind the great difficulties with accessing them due to the decreasing response rates in executive surveys?". The article proposes, as one of the possible solutions to this problem, the use of content analysis, which is successfully applied in sociology 5 . The words used in daily life reflect what people are focused on, what are they thinking about

1 This article has been developed with the funding from National Science Centre, Poland - project no. 2017/25/N/HS4/02037.

2 K. Szczepaniak, Zastosowanie analizy treści w badaniach artykułów prasowych - refleksje metodologiczne, "Acta Universitatis Lodziensis. Folia Sociologica” 2012, vol. 42, pp. 83-112.

3 R.E. Hoskisson et al., Managerial risk taking: A multitheoretical review and future research agenda, "Journal of Management" 2017, vol. 43, no. 1, pp. 137-169.

4 C.S. Cycyota, D.A. Harrison, What (not) to expect when surveying executives: A meta-analysis of top manager response rates and techniques over time, "Organizational Research Methods" 2006, vol. 9, no. 2, pp. 133-160.

5 K. Szczepaniak, Zastosowanie analizy treści... 
or how they feel ${ }^{6}$. And the new technologies that create and archive digital traces offer researchers a novel, large-scale data which reflects people's actual behaviors that can be rapidly collected and analyzed by new tools?

This paper aims to present the potential of content analysis as an effective and cutting-edge method to study the psychological traits of firms' hard-to-reach core decision makers. In order to do that, the authors conducted a systematic literature review of articles from multiple databases (i.e. Web of Science, Scopus, and Google Scholar), limited to the period of 2009-2019. The analysis targeted 13 management articles that employed content analysis as the method to assess psychological traits of individual managers (Table 2).

\section{Characteristics of content analysis}

Content analysis as a methodological tool firstly appeared in the literature in the early $1940 s^{8}$. In its early stage, it focused on the identification of manifested content. The technique was later expanded to include the domain of qualitative methods, focusing on both manifested and latent content ${ }^{9}$. Nowadays, a wide range of theoretical frameworks, methods, and analytical techniques have been labeled content analysis. It is an entire class of methods at the intersection of the qualitative and quantitative traditions ${ }^{10}$, recognized for its value in uncovering replicable and valid inferences from a body of text - i.e., words, phrases, and language used by individuals in speeches, organizational narratives or other communication media ${ }^{11}$.

6 Y.R. Tausczik, J.W. Pennebaker, The Psychological Meaning of Words: LIWC and Computerized Text Analysis Methods, "Journal of Language and Social Psychology” 2010, vol. 29, no. 1, pp. 24-54.

7 A. Rafaeli, S. Ashtar, D. Altman, Digital Traces: New Data, Resources, and Tools for Psychological-Science Research, "Current Directions in Psychological Science” 2019, vol. 28, no. 6, pp. 560-566.

8 K. Krippendorf, Content analysis: An introduction to its methodology, Sage Publications, Thousand Oaks 2004.

9 The content is manifested, when the analysis focuses on easily observable meanings in a body of text. The content is latent, when the analysis focuses of the underlying meanings of texts - A. Gaur, M. Kumar, A systematic approach to conducting review studies: An assessment of content analysis in 25 years of IB research, "Journal of World Business" 2018, vol. 53, pp. 280-289.

10 V.J. Duriau, R.K. Reger, M.D. Pfarrer, A content analysis of the content analysis literature in organization studies: Research themes, data sources, and methodological refinements, "Organizational Research Methods" 2007, vol. 10, no. 1, pp. 5-34.

11 B. Szymczyk, W. Żakowicz, K. Stemplewska-Żakowicz, Automatyczna analiza tekstu: polska adaptacja programu LIWC Jamesa Pennebakera, "Przegląd Psychologiczny" 2012, vol. 55, no. 2, pp. 195-209. 
According to the classical definition by Bernard Berelson, from 1952, content analysis is a research technique for the objective, systematic and quantitative description of explicit content of messages. The most questionable aspect of this definition is the assumption that the message's meaning is always consistent with the intentions of the sender and free from understatements and overinterpretation. It is postulated that the researcher should have a certain leeway to draw conclusions based on the examined material. Therefore, one can conclude not only from what was written in the texts, but also from what was left unsaid ${ }^{12}$.

There are four stages of content analysis: data collection, coding, analysis, and interpretation of coded content. In the first, the data collection stage, researchers select their data sources and identify sampling criteria. To select valid samples, it is essential for researchers to understand the relationships between source databases, sample characteristics, and research questions. In the second stage, the collected textual data are coded into different categories at various levels (recording units): words, phrases, sentences, paragraphs, or themes. In order to develop valid coding schemes, researchers use the 8-step Weber Protocol: (1) Definition of the recording units; (2) Definition of the coding categories; (3) Test of coding on a sample of text; (4) Assessment of the accuracy and reliability of the sample coding; (5) Revision of the coding rules; (6) Return to Step 3 until sufficient reliability is achieved; (7) Coding of all the text; (8) Assessment of the achieved reliability or accuracy. In the third stage, which is analysis of content, researchers can use various formats to present their observations. The vast majority of research relied on simple counts. The fourth and final stage is the interpretation of results within the theoretical framework, depending on the research purpose: measurement, description, or inference ${ }^{13}$.

Content analysis has a number of methodological advantages over other research methods. Foremost to management research, it provides a replicable methodology to access deep individual structures. As such, content analysis is applicable to those important but difficult-to-study issues of interest to management researchers, such as managerial cognition ${ }^{14}$. This is due to its unobtrusive nature ${ }^{15}$. Being unobtrusive is particularly relevant to the study of senior executives, as access to information from this source is often a serious issue. Moreover, because of the availability of comparable corporate information over a certain timeframe (such as annual reports or trade magazines) longitudinal research designs of these managers can be implemented ${ }^{16}$.

12 K. Szczepaniak, Zastosowanie analizy treści...

13 V.J. Duriau, R.K. Reger, M.D. Pfarrer, A content analysis...

14 C.S. Cycyota, D.A. Harrison, What (not) to expect...

15 K. Szczepaniak, Zastosowanie analizy treści...

16 V.J. Duriau, R.K. Reger, M.D. Pfarrer, A content analysis... 
Given recent advances in computer-aided techniques, content analysis can cope with large volumes of unstructured data. Computer-aided text analysis (CATA) is a form of content analysis that enables the measurement of constructs by processing text into quantitative data based on the frequency of words. CATA has been used to analyze large sets of qualitative data at high speed that have allowed scholars to answer questions surrounding behaviors and motivations of individuals. These programs are constructed in a way to enable and facilitate the work with the tested material by cataloging, organizing, as well as providing advanced search capabilities. They improve exploration, analysis and presentation of synthesized data ${ }^{17}$.

Qualitative analysis programs differ not only in terms of the type of functions available, but also in the scope of activities within the same functions and how to access certain data and aspects of analysis. Depending on the type of analytical activities, four types of programs can be distinguished that support: (1) arithmetic (quantitative) analysis, (2) collection and editing of textual data, (3) organization and management of various types of data, and (4) support of theory creation process $^{18}$. When choosing the software, researcher must be aware of what the research goal is, the type of data or the method used, as well as the method of analysis ${ }^{19}$. Examples of this software are shown in Table 1.

Table 1. Types of computer programs for qualitative data analysis (CATA)

\begin{tabular}{|l|l|}
\hline \multicolumn{1}{|c|}{ Types of programs } & \multicolumn{1}{c|}{ Names of programs } \\
\hline Arithmetic (quantitative) analysis & MAX, Tabletop, Spad.t \\
\hline Collection and editing of textual data & $\begin{array}{l}\text { askSam, Folio Views, MAX, Tabletop, } \\
\text { HyperQual2, QSR N6 (NUD*.IST), Martin, } \\
\text { QUALPRO, The Ethnograph, Kwalitan. }\end{array}$ \\
\hline $\begin{array}{l}\text { Organization and management of various } \\
\text { types of data }\end{array}$ & askSam, HyperQual2, FolioViews, Orbis, MAX \\
\hline Support of theory creation process & $\begin{array}{l}\text { NUD*IST, ATLAS.ti, MECA, MetaDesign, } \\
\text { SemNet, QCA, ETHNO, Inspiration, for } \\
\text { hypothesis testing: HyperRESEARCH, AQUAD. }\end{array}$ \\
\hline
\end{tabular}

Source: J. Bieliński, K. Iwińska, A. Rosińska-Kordasiewicz, Analiza danych jakościowych przy użyciu programów komputerowych, "ASK” 2007, vol. 16, p. 97.

17 J. Bieliński, K. Iwińska, A. Rosińska-Kordasiewicz, Analiza danych jakościowych przy użyciu programów komputerowych, "ASK” 2007, vol. 16, pp. 89-114.

18 J. Bieliński, K. Iwińska, A. Rosińska-Kordasiewicz, Analiza danych jakościowych...

19 J. Niedbalski, Komputerowe wspomaganie analizy danych jakościowych (CAQDAS) w projektowaniu i prowadzeniu badań, “Nauka i Szkolnictwo Wyższe” 2013, vol. 1/41, pp. 185-202. 


\section{Content analysis in management research}

The past two decades have seen an "increasing scholarly interest in qualitative methodologies to study complex business phenomena, by borrowing and adapting from more established disciplines" 20 . Recent literature using content analysis has made particularly worthy contributions in the area of managerial and organizational cognition ${ }^{21}$, a topic which goes back at least to Kets de Vries and colleagues ${ }^{22}$. The most important leadership function in any firm is performed by the $\mathrm{CEO}^{23}$, who is responsible for setting up the strategy ${ }^{24}$, with CEO communication as the core managerial cognitive capability that underpins the firm-level outcomes ${ }^{25}$.

The empirical literature in management has been long studying the effect of CEO communication on firm-level outcomes ${ }^{26}$. However, a persistent challenge for research on top executives has been the limited ability to obtain valid and reliable measures of their personality traits. The challenges associated with surveying CEOs have limited both the number and sample sizes of studies. As an alternative to using the traditional ways, some scholars have recently used word-count software to identify keywords in texts attributed to $\mathrm{CEO}^{27}$.

According to Duriau, Reger, and $\mathrm{Pfarrer}^{28}$, annual reports are the most frequently used sources of content analysis in management research. They are the primary materials to study the interaction of firms with their environment, having several

20 J.S. Harrison et al., Measuring CEO personality: Developing, validating, and testing a linguistic tool, "Strategic Management Journal" 2019, vol. 40, no. 8, pp. 1316-1330.

21 V.J. Duriau, R.K. Reger, M.D. Pfarrer, A content analysis...

22 M.F.R. Kets De Vries, D. Miller, Neurotic style and organizational pathology, "Strategic Management Journal" 1984, vol. 5, no. 1, pp. 35-55.

23 E.g., A. Chatterjee, D.C. Hambrick, It's all about me: Narcissistic chief executive officers and their effects on company strategy and performance, "Administrative Science Quarterly" 2007, vol. 52, no. 3, pp. 351-386; R.S. Peterson et al., The impact of chief executive officer personality on top management team dynamics: One mechanism by which leadership affects organizational performance, "Journal of Applied Psychology" 2003, vol. 88, no. 5, pp. 795-808.

24 D.C. Hambrick, P.A. Mason, Upper echelons: The organization as a reflection of its top managers, "Academy of Management Review" 1984, vol. 9, no. 2, pp. 193-206.

25 CEOs' communication style includes both verbal and nonverbal forms of expression - C.E. Helfat, M.A. Peteraf, Managerial cognitive capabilities and the microfoundations of dynamic capabilities, "Strategic Management Journal” 2015, vol. 36, no. 6, pp. 831-850; P. Choudhury et al., Machine learning approaches to facial and text analysis: Discovering CEO oral communication styles, "Strategic Management Journal" 2019, vol. 40, pp. 1705-1732.

26 E.g., R.A. D'Aveni, I.C. MacMillan, Crisis and the content of managerial communications: A Study of the focus of attention of top managers in surviving and failing firms, "Administrative Science Quarterly" 1990, vol. 35, no. 4, pp. 634-657.

27 J.S. Harrison et al., Measuring CEO personality...

28 V.J. Duriau, R.K. Reger, M.D. Pfarrer, A content analysis... 
advantages over other sources of corporate information to study cognitive phenomena. These advantages are due to their unobtrusive and longitudinal character ${ }^{29}$. As can be seen in Table 2, their predominance in management studies in the last decade has continued, particularly one outlet, i.e. shareholder letters.

CEO letters are corporate narratives with high diversity in vocabulary and lexical variety, providing considerable opportunity to direct attention, establish focus on prevalent events and affect external perception. In these letters, the CEO can comment on company actions, events, performance and outcomes. They are full of linguistic devices that hold interactional cues of both rational and affective appeal that reflect CEO's purposive editorializing ${ }^{30}$.

Table 2. Management studies from 2009-2019, utilizing content analysis as the method to assess psychological traits of individual managers

\begin{tabular}{|l|l|l|l|l|l|}
\hline No. & Authors & Year & $\begin{array}{l}\text { Source of con- } \\
\text { tent analysis }\end{array}$ & $\begin{array}{c}\text { Psychological } \\
\text { traits assessed } \\
\text { with content } \\
\text { analysis } \\
\text { (variables) }\end{array}$ & $\begin{array}{l}\text { Concluding remarks regarding } \\
\text { variables assessed with content } \\
\text { analysis }\end{array}$ \\
\hline 1 & $\begin{array}{l}\text { Behr and } \\
\text { Fehre }\end{array}$ & 2019 & $\begin{array}{l}\text { Shareholder } \\
\text { letters }\end{array}$ & $\begin{array}{l}\text { CEO CSQ } \\
\text { (independent) }\end{array}$ & $\begin{array}{l}\text { CSQ does not increase } \\
\text { continuously over time but } \\
\text { it alters after a first, short, } \\
\text { stage of incumbency due } \\
\text { to "newness" in the CEO } \\
\text { position and does not increase } \\
\text { significantly in later stages. }\end{array}$ \\
\hline 2 & $\begin{array}{l}\text { Buyl, } \\
\text { Boone, and }\end{array}$ & 2019 & $\begin{array}{l}\text { Shareholder } \\
\text { letters }\end{array}$ & $\begin{array}{l}\text { CEO narcissism } \\
\text { (independent) }\end{array}$ & $\begin{array}{l}\text { The combination of CEO } \\
\text { narcissism and specific CGb } \\
\text { practices leads towards } \\
\text { (excessive) risk-taking; thus, } \\
\text { an organization's CG policies can } \\
\text { make a real difference in reining } \\
\text { in narcissistic CEOs. }\end{array}$ \\
\hline $\begin{array}{l}\text { Recovery after the September } \\
\text { 2008 collapse was slower } \\
\text { in banks with a more narcissistic } \\
\text { CEO, and this effect was } \\
\text { partially mediated by banks pre- } \\
\text { shock riskiness of policies. }\end{array}$ \\
\hline
\end{tabular}

29 E.H. Bowman, Content analysis of annual reports for corporate strategy and risk, "Interfaces" 1984, vol. 14, no. 1, pp. 61-71.

30 B. Yan, W. Aerts, J. Thewissen, The informativeness of impression management - financial analysts and rhetorical style of CEO letters, "Pacific Accounting Review" 2019, vol. 31, no. 3 , pp. 462-496. 


\begin{tabular}{|c|c|c|c|c|c|}
\hline No. & Authors & Year & $\begin{array}{l}\text { Source of con- } \\
\text { tent analysis }\end{array}$ & $\begin{array}{c}\text { Psychological } \\
\text { traits assessed } \\
\text { with content } \\
\text { analysis } \\
\text { (variables) } \\
\end{array}$ & $\begin{array}{c}\text { Concluding remarks regarding } \\
\text { variables assessed with content } \\
\text { analysis }\end{array}$ \\
\hline \multirow[t]{3}{*}{3} & \multirow[t]{3}{*}{$\begin{array}{l}\text { Chang, Lee, } \\
\text { and Oh }\end{array}$} & \multirow[t]{3}{*}{2018} & \multirow[t]{3}{*}{$\begin{array}{l}\text { Shareholder } \\
\text { letters }\end{array}$} & \multirow[t]{3}{*}{$\begin{array}{l}\text { CEO regulatory } \\
\text { focus } \\
\text { (independent) }\end{array}$} & $\begin{array}{l}\text { Promotional CEOs (CEOs with } \\
\text { predominant promotion focus) } \\
\text { are more engaged in CSRC even } \\
\text { when the industry-level and } \\
\text { firm-level dynamisms are high. }\end{array}$ \\
\hline & & & & & $\begin{array}{l}\text { CEOs with a promotion focus } \\
\text { seem to be more active } \\
\text { in stakeholder management, } \\
\text { whereas CEOs with a prevention } \\
\text { focus may not make as much } \\
\text { of a difference in this regard } \\
\text { as promotional CEOs. }\end{array}$ \\
\hline & & & & & $\begin{array}{l}\text { CEO regulatory focus interacts } \\
\text { with industry-level and firm- } \\
\text { level dynamisms to affect CSR. }\end{array}$ \\
\hline \multirow[t]{2}{*}{4} & \multirow[t]{2}{*}{$\begin{array}{l}\text { Eggers and } \\
\text { Kaplan }\end{array}$} & \multirow[t]{2}{*}{2009} & \multirow[t]{2}{*}{$\begin{array}{l}\text { Shareholder } \\
\text { letters }\end{array}$} & \multirow[t]{2}{*}{$\begin{array}{l}\text { CEO attention } \\
\text { (independent) }\end{array}$} & $\begin{array}{l}\text { Managerial cognition } \\
\text { is associated with differences } \\
\text { in the timing of entry into a new } \\
\text { product market. }\end{array}$ \\
\hline & & & & & $\begin{array}{l}\text { The effect of CEOs cognition } \\
\text { is context-specific. It differs } \\
\text { depending on the focus } \\
\text { of their attention, the level } \\
\text { of organizational orientation, } \\
\text { and whether firms possess } \\
\text { greater industry-related } \\
\text { capabilities. }\end{array}$ \\
\hline \multirow[t]{2}{*}{5} & \multirow[t]{2}{*}{$\begin{array}{l}\text { Gamache, } \\
\text { McNamara, } \\
\text { Mannor, } \\
\text { and } \\
\text { Johnson }\end{array}$} & \multirow[t]{2}{*}{2015} & \multirow[t]{2}{*}{$\begin{array}{l}\text { Shareholder } \\
\text { letters }\end{array}$} & \multirow[t]{2}{*}{$\begin{array}{l}\text { CEO regulatory } \\
\text { focus } \\
\text { (independent) }\end{array}$} & $\begin{array}{l}\text { CEO regulatory focus impacts } \\
\text { both the quantity and scale } \\
\text { of acquisitions undertaken } \\
\text { by a firm. }\end{array}$ \\
\hline & & & & & $\begin{array}{l}\text { Relationships between CEOs } \\
\text { with predominant promotion } \\
\text { focus and both quantity and } \\
\text { scale of acquisitions undertaken } \\
\text { by a firm are moderated } \\
\text { by stock option pay. }\end{array}$ \\
\hline
\end{tabular}


Table 2 (continued)

\begin{tabular}{|c|c|c|c|c|c|}
\hline No. & Authors & Year & $\begin{array}{c}\text { Source of con- } \\
\text { tent analysis }\end{array}$ & $\begin{array}{l}\text { Psychological } \\
\text { traits assessed } \\
\text { with content } \\
\text { analysis } \\
\text { (variables) }\end{array}$ & $\begin{array}{c}\text { Concluding remarks regarding } \\
\text { variables assessed with content } \\
\text { analysis }\end{array}$ \\
\hline \multirow[t]{2}{*}{6} & \multirow[t]{2}{*}{$\begin{array}{l}\text { Gamache } \\
\text { and } \\
\text { McNamara }\end{array}$} & \multirow[t]{2}{*}{2019} & \multirow[t]{2}{*}{$\begin{array}{l}\text { Shareholder } \\
\text { letters }\end{array}$} & \multirow[t]{2}{*}{$\begin{array}{l}\text { CEO past focus } \\
\text { (moderating); } \\
\text { CEO future } \\
\text { focus } \\
\text { (moderating) }\end{array}$} & $\begin{array}{l}\text { CEO temporal focus (disposition } \\
\text { that reflects the degree to which } \\
\text { individual attention is directed } \\
\text { toward the past, present, and } \\
\text { future) shapes which CEOs } \\
\text { will be influenced by media } \\
\text { reactions. }\end{array}$ \\
\hline & & & & & $\begin{array}{l}\text { A CEOs' propensity } \\
\text { to be influenced by stock market } \\
\text { reactions is not moderated } \\
\text { by their temporal focus. }\end{array}$ \\
\hline \multirow[t]{3}{*}{7} & \multirow[t]{3}{*}{$\begin{array}{l}\text { Kashmiri, } \\
\text { Gala, and } \\
\text { Nicol }\end{array}$} & \multirow[t]{3}{*}{2019} & \multirow[t]{3}{*}{$\begin{array}{l}\text { Shareholder } \\
\text { letters }\end{array}$} & \multirow[t]{3}{*}{$\begin{array}{l}\text { CEO regulatory } \\
\text { focus } \\
\text { (independent) }\end{array}$} & $\begin{array}{l}\text { Firms whose CEOs are } \\
\text { predominantly promotion- } \\
\text { focused tend to have higher } \\
\text { levels of advertising and } \\
\text { R\&Dd intensities. On the other } \\
\text { hand, firms led by such CEOs are } \\
\text { also more likely to get involved } \\
\text { in marketing controversies. }\end{array}$ \\
\hline & & & & & $\begin{array}{l}\text { The impact of a CEO's regulatory } \\
\text { focus is, on the whole, } \\
\text { strengthened when the CEO } \\
\text { has high power and low stock } \\
\text { option-compensation ratio, and } \\
\text { when the firm operates under } \\
\text { high environmental dynamism. }\end{array}$ \\
\hline & & & & & $\begin{array}{l}\text { CEO power does not moderate } \\
\text { the impact of CEO regulatory } \\
\text { focus on a firms' advertising } \\
\text { intensity. }\end{array}$ \\
\hline 8 & $\begin{array}{l}\text { Keil, Maula, } \\
\text { and Syrigos }\end{array}$ & 2017 & $\begin{array}{l}\text { Shareholder } \\
\text { letters }\end{array}$ & $\begin{array}{l}\text { CEO } \\
\text { entrepreneurial } \\
\text { orientation } \\
\text { (independent) }\end{array}$ & $\begin{array}{l}\text { CEO entrepreneurial orientation } \\
\text { enhances firm value creation } \\
\text { and this positive effect } \\
\text { is reduced when CEOs are } \\
\text { entrenched (1) due to CG } \\
\text { provisions that protect } \\
\text { them from the majority will } \\
\text { of shareholders, (2) due } \\
\text { to substantial ownership that } \\
\text { provides them with too much } \\
\text { decision-making power, or (3) } \\
\text { due to substantial ownership } \\
\text { held by the CEO's family. }\end{array}$ \\
\hline
\end{tabular}




\begin{tabular}{|c|c|c|c|c|c|}
\hline No. & Authors & Year & $\begin{array}{l}\text { Source of con- } \\
\text { tent analysis }\end{array}$ & $\begin{array}{c}\text { Psychological } \\
\text { traits assessed } \\
\text { with content } \\
\text { analysis } \\
\text { (variables) } \\
\end{array}$ & $\begin{array}{c}\text { Concluding remarks regarding } \\
\text { variables assessed with content } \\
\text { analysis }\end{array}$ \\
\hline 9 & Knust & 2017 & $\begin{array}{l}\text { Shareholder } \\
\text { letters }\end{array}$ & $\begin{array}{l}\text { CEO regulatory } \\
\text { focus } \\
\text { (independent) }\end{array}$ & $\begin{array}{l}\text { The higher the intensity } \\
\text { of change, the organization } \\
\text { is actually executing, the higher } \\
\text { the promotion focus of CEOs. }\end{array}$ \\
\hline \multirow[t]{3}{*}{10} & \multirow[t]{3}{*}{$\begin{array}{l}\text { Malhotra, } \\
\text { Reus, } \\
\text { Zhu, and } \\
\text { Roelofsen }\end{array}$} & \multirow[t]{3}{*}{2018} & \multirow{3}{*}{$\begin{array}{l}\text { Text spoken } \\
\text { by a CEO } \\
\text { in response } \\
\text { to questions } \\
\text { in Q\&A segment } \\
\text { of quarterly } \\
\text { earnings } \\
\text { conference calls } \\
\text { with financial } \\
\text { analysts }\end{array}$} & \multirow[t]{3}{*}{$\begin{array}{l}\text { CEO Big Five } \\
\text { - extraversion } \\
\text { (independent) }\end{array}$} & $\begin{array}{l}\text { Extraverted CEOs are more } \\
\text { likely to engage in acquisitions, } \\
\text { and to conduct larger ones, } \\
\text { than other CEOs and these } \\
\text { effects are partially explained } \\
\text { by their greater representation } \\
\text { on boards of other firms. } \\
\end{array}$ \\
\hline & & & & & $\begin{array}{l}\text { The acquisitive nature } \\
\text { of extraverted CEOs reveals } \\
\text { itself particularly in so-called } \\
\text { "weaker" situations, in which } \\
\text { CEOs enjoy considerable } \\
\text { discretion to behave in ways } \\
\text { akin to their personality traits. } \\
\end{array}$ \\
\hline & & & & & $\begin{array}{l}\text { Extraverted CEOs are more likely } \\
\text { than other CEOs to succeed } \\
\text { in } \mathrm{M} \& \mathrm{~A}^{\mathrm{e}} \text {, as reflected by stronger } \\
\text { abnormal returns following } \\
\text { acquisition announcements. }\end{array}$ \\
\hline 11 & $\begin{array}{l}\text { McClelland, } \\
\text { Liang, and } \\
\text { Barker }\end{array}$ & 2010 & $\begin{array}{l}\text { Shareholder } \\
\text { letters }\end{array}$ & $\begin{array}{l}\text { CEO CSQ } \\
\text { (independent) }\end{array}$ & $\begin{array}{l}\text { In high-discretion industries, } \\
\text { firms whose CEOs are } \\
\text { committed to the status } \\
\text { quo suffer future financial } \\
\text { and market performance } \\
\text { declines compared with their } \\
\text { competitors, whereas such } \\
\text { performance deterioration does } \\
\text { not occur in low-discretion } \\
\text { environments. }\end{array}$ \\
\hline 12 & $\begin{array}{l}\text { Nadkarni } \\
\text { and Chen }\end{array}$ & 2014 & $\begin{array}{l}\text { Shareholder } \\
\text { letters; press } \\
\text { releases; } \\
\text { speeches; } \\
\text { interview } \\
\text { transcripts }\end{array}$ & $\begin{array}{l}\text { CEO temporal } \\
\text { focus } \\
\text { (independent) }\end{array}$ & $\begin{array}{l}\text { In stable environments, new } \\
\text { products are introduced faster } \\
\text { in firms headed by CEOs with } \\
\text { high past focus, high present } \\
\text { focus, and low future focus. } \\
\text { In dynamic environments, new } \\
\text { products are introduced faster } \\
\text { in firms headed by CEOs with } \\
\text { low past focus, high present } \\
\text { focus, and high future focus. }\end{array}$ \\
\hline
\end{tabular}


Table 2 (continued)

\begin{tabular}{|l|l|l|l|l|l|}
\hline No. & Authors & Year & $\begin{array}{c}\text { Source of con- } \\
\text { tent analysis }\end{array}$ & $\begin{array}{c}\text { Psychological } \\
\text { traits assessed } \\
\text { with content } \\
\text { analysis } \\
\text { (variables) }\end{array}$ & $\begin{array}{c}\text { Concluding remarks regarding } \\
\text { variables assessed with content } \\
\text { analysis }\end{array}$ \\
\hline 13 & $\begin{array}{l}\text { Patelli and } \\
\text { Pedrini }\end{array}$ & 2013 & $\begin{array}{l}\text { Shareholder } \\
\text { letters }\end{array}$ & $\begin{array}{l}\text { CEO optimism } \\
\text { (independent) }\end{array}$ & $\begin{array}{l}\text { An optimistic tone } \\
\text { in shareholder letters } \\
\text { is congruent with both past and } \\
\text { future performance. }\end{array}$ \\
\hline
\end{tabular}

a CSQ - commitment to the status quo; b CG - corporate governance; c CSR - corporate social responsibility; ${ }^{d} R \& D$ - research and development; e $M \& A$ - mergers and acquisitions.

Source: own work.

\section{Conclusions}

This paper identifies various methodological approaches of collecting data unobtrusively from executive written communication, showing the possible way for management scientists to bypass the fundamental limitations of collecting psychological data from primary sources. The findings from reviewed studies strongly support the notion that the psychological traits of CEOs, as core decision makers, impacts a firms' strategy and performance indicators, and that these traits can be effectively assessed with content analysis. They also point at shareholder letters as a relevant source of such assessment due to their longitudinal availability for a large sample of firms.

Content analysis is, however, not without its flaws. When done entirely by hand it is time-consuming ${ }^{31}$. On the other hand, the main objection regarding the use of CATA software in content analysis is its rigidity, which subordinates the analysis to solutions implemented by the tool developers. Thus, it is pointed out that the computer program narrows the field of researcher's activity, which is contrary to the spirit of qualitative research methodology 32 .

Annual reports have also been criticized in managerial-cognition research. Some researchers say that shareholder letters may be the result of Public Relations activities, and therefore may be not come from the actual managers ${ }^{33}$. Even if this is true in some cases, CEOs spend extensive time outlining the majority of the

31 K. Krippendorf, Content analysis...

32 J. Niedbalski, Komputerowe wspomaganie analizy...

33 P.C. Fiss, E.J. Zając, The symbolic management of strategic change: Sensegiving via framing and decoupling, "Academy of Management Journal" 2006, vol. 49, no. 6, pp. 1173-1193. 
content, making extensive corrections and adding their slant ${ }^{34}$. This is because whoever's signature is on the document is responsible for its content in a legal sense before any financial supervision authority and, in a social sense, to the many stakeholders ${ }^{35}$. There are numerous studies that have adopted content analysis of shareholder letters and confirmed the validity of this research method ${ }^{36}$. Any criticism of this approach must take into account the undoubted advantage in studying the characteristics of the psychology of CEOs, in that it provides a discrete and consistent annual measure for long-term analysis ${ }^{37}$. Although this process is not without its flaws, achieving an approximate description of CEO is better than employing those methods with a meagre response rates.

There is also the question of whether the findings are applicable in other than a predominantly U.S. cultural context ${ }^{38}$. Some scholars have suggested that cultural differences among CEOs can impact shareholder letters. For example, Huang and Rose found that the letters of Western CEO tend to use more credibility and affective appeals, while Chinese CEOs' letters are based more on rational appeals ${ }^{39}$. On the other hand, Hooghiemstra found that U.S. and Japanese CEOs' letters do not vary in the communication of good news ${ }^{40}$. Another study by Conaway and Wardrope found that the same strategic characteristics in the letters of CEOs existed across both Latin American and U.S. samples ${ }^{41}$. Therefore, the authors' preliminary analysis of the literature does not indicate any significant premises for restrictions on the use of the method in different cultural contexts.

34 E.H. Bowman, Content analysis...

35 J.P. Daly, R.W. Pouder, B. Kabanoff, The effects of initial differences in firms' espoused values on their postmerger performance, "The Journal of Applied Behavioral Science" 2004, vol. 40, no. 3, pp. 323-343.

36 E.g., S.E. Clapham, C.R. Schwenk, Self-serving attributions, managerial cognition, and company performance, "Strategic Management Journal" 1991, vol. 12, no. 3, pp. 219-229; R.A. D'Aveni, I.C. MacMillan, Crisis and the content...; C.M. Fiol, Corporate communications: Comparing executives' private and public statements, "Academy of Management Journal" 1995, vol. 38, no. 2, pp. 522-536.

37 O. Levy, The influence of top management team attention patterns on global strategic posture of firms, "Journal of Organizational Behavior" 2005, vol. 26, no. 7, pp. 797-819.

$38 \mathrm{H}$. Behr, K. Fehre, CEO succession and the CEO's commitment to the status quo, "Business Research" 2019, vol. 12, pp. 355-381.

39 Y. Huang, K. Rose, You, our shareholders: metadiscourse in CEO letters from Chinese and Western banks, "Text\&Talk" 2018, vol. 38, no. 2, pp. 167-190.

40 R. Hooghiemstra, Letters to the shareholders: A content analysis comparison of letters written by CEOs in the United States and Japan, "The International Journal of Accounting" 2010, vol. 45, no. 3, pp. 275-300.

41 R.N. Conaway, W.J. Wardrope, Do their words really matter? Thematic analysis of U.S. and Latin American CEO letters, "Journal of Business Communication” 2010, vol. 47, no. 2, pp. 141-168. 
Due to the abovementioned limitations, future research should both adopt richer conceptual frameworks, combining content analysis with ethnographic or cultural approaches, and also incorporate a wide variety of external and internal documents, other than shareholder letters ${ }^{42}$. Another promising avenue for future research is broadening the content analytic approach. This can be done by triangulating the alternative methodological approaches in order to study both verbal and nonverbal CEO communication ${ }^{43}$, as well as written texts ${ }^{44}$.

\section{References}

Behr H., Fehre K., CEO succession and the CEO's commitment to the status quo, "Business Research" 2019, vol. 12, pp. 355-381.

Bieliński J., Iwińska K., Rosińska-Kordasiewicz A., Analiza danych jakościowych przy użyciu programów komputerowych, "ASK" 2007, vol. 16, pp. 89-114.

Bowman E.H., Content analysis of annual reports for corporate strategy and risk, "Interfaces" 1984, vol. 14, no. 1, pp. 61-71.

Buyl T., Boone C., Wade J.B., CEO Narcissism, Risk-Taking, and Resilience: An Empirical Analysis in U.S. Commercial Banks, "Journal of Management" 2019, vol. 45, no. 4, pp. 1372-1400.

Chang Y.K., Lee S., Oh W.-Y., Approaching gain or avoiding loss? The impact of CEO regulatory focus and dynamism on CSR, "Academy of Management Proceedings" 2018, vol. 1, pp. 1-6.

Chatterjee A., Hambrick D.C., It's all about me: Narcissistic chief executive officers and their effects on company strategy and performance, "Administrative Science Quarterly" 2007, vol. 52, no. 3, pp. 351-386.

Choudhury P., Wang D., Carlson N.A., Khanna T., Machine learning approaches to facial and text analysis: Discovering CEO oral communication styles, "Strategic Management Journal" 2019, vol. 40, pp. 1705-1732.

Clapham S.E., Schwenk C.R., Self-serving attributions, managerial cognition, and company performance, "Strategic Management Journal" 1991, vol. 12, no. 3, pp. 219-229.

Conaway R.N., Wardrope W.J., Do their words really matter? Thematic analysis of U.S. and Latin American CEO letters, “Journal of Business Communication” 2010, vol. 47, no. 2, pp. 141-168.

Cycyota C.S., Harrison D.A., What (not) to expect when surveying executives: A meta-analysis of top manager response rates and techniques over time, "Organizational Research Methods" 2006, vol. 9, no. 2, pp. 133-160.

D'Aveni R.A., MacMillan I.C., Crisis and the content of managerial communications: A Study of the Focus of Attention of Top Managers in Surviving and Failing Firms, "Administrative Science Quarterly" 1990, vol. 35, no. 4, pp. 634-657.

Daly J.P., Pouder R.W., Kabanoff B., The effects of initial differences in firms' espoused values on their postmerger performance, "The Journal of Applied Behavioral Science" 2004, vol. 40, no. 3, pp. 323-343.

Duriau V.J., Reger R.K., Pfarrer M.D., A content analysis of the content analysis literature in organization studies: Research themes, data sources, and methodological refinements, "Organizational Research Methods" 2007, vol. 10, no. 1, pp. 5-34.

42 V.J. Duriau, R.K. Reger, M.D. Pfarrer, $A$ content analysis...

43 P. Choudhury et al., Machine learning approaches...

44 C.E. Helfat, M.A. Peteraf, Managerial cognitive capabilities... 
Eggers J.P., Kaplan S., Cognition and Renewal: Comparing CEO and Organizational Effects on Incumbent Adaptation to Technical Change, "Organization Science" 2009, vol. 20, no. 2, pp. 461-477.

Fiol C.M., Corporate communications: Comparing executives' private and public statements, "Academy of Management Journal" 1995, vol. 38, no. 2, pp. 522-536.

Fiss P.C., Zając E.J., The symbolic management of strategic change: Sensegiving via framing and decoupling, "Academy of Management Journal" 2006, vol. 49, no. 6, pp. 1173-1193.

Gamache D.L., McNamara G., Responding to Bad Press: How CEO Temporal Focus Influences the Sensitivity to Negative Media Coverage of Acquisitions, "Academy of Management Journal" 2019, vol. 62, no. 3, pp. 918-943.

Gamache D.L., McNamara G., Mannor M.J., Johnson R.E., Motivated to acquire? The impact of CEO regulatory focus on firm acquisitions, "Academy of Management Journal" 2015, vol. 58, no. 4, pp. 1261-1282.

Gaur A., Kumar M., A systematic approach to conducting review studies: An assessment of content analysis in 25 years of IB research, "Journal of World Business" 2018, vol. 53, pp. 280-289.

Hambrick D.C., Mason P.A., Upper echelons: The organization as a reflection of its top managers, "Academy of Management Review" 1984, vol. 9, no. 2, pp. 193-206.

Harrison J.S., Thurgood G.R., Boivie S., Pfarrer M.D., Measuring CEO personality: Developing, validating, and testing a linguistic tool, "Strategic Management Journal" 2019, vol. 40, no. 8 , pp. 1316-1330.

Helfat C.E., Peteraf M.A., Managerial cognitive capabilities and the microfoundations of dynamic capabilities, "Strategic Management Journal" 2015, vol. 36, no. 6, pp. 831-850.

Hooghiemstra R., Letters to the shareholders: A content analysis comparison of letters written by CEOs in the United States and Japan, "The International Journal of Accounting" 2010, vol. 45, no. 3, pp. 275-300.

Hoskisson R.E., Chirico F., Zyung J.(D.), Gambeta E., Managerial risk taking: A multitheoretical review and future research agenda, "Journal of Management" 2017, vol. 43, no. 1, pp. 137-169.

Huang Y., Rose K., You, our shareholders: metadiscourse in CEO letters from Chinese and Western banks, "Text\&Talk" 2018, vol. 38, no. 2, pp. 167-190.

Kashmiri S., Gala P., Nicol C.D., Seeking pleasure or avoiding pain: Influence of CEO regulatory focus on firms' advertising, R\&D, and marketing controversies, "Journal of Business Research" 2019, vol. 105, pp. 227-242.

Keil T., Maula M., Syrigos E., CEO Entrepreneurial Orientation, Entrenchment, and Firm Value Creation, "Entrepreneurship Theory and Practice" 2017, vol. 41, no. 4, pp. 475-504.

Kets De Vries M.F.R., Miller D., Neurotic style and organizational pathology, "Strategic Management Journal" 1984, vol. 5, no. 1, pp. 35-55.

Knust P., CEO Communication during Strategic Change: A Regulatory Focus Perspective, "Junior Management Science" 2017, vol. 2, no. 1, pp. 1-16.

Krippendorf K., Content analysis: An introduction to its methodology, Sage Publications, Thousand Oaks 2004.

Levy O., The influence of top management team attention patterns on global strategic posture of firms, "Journal of Organizational Behavior" 2005, vol. 26, no. 7, pp. 797-819.

Malhotra S., Reus T.H., Zhu P.C., Roelofsen E.M., The Acquisitive Nature of Extraverted CEOs, "Administrative Science Quarterly" 2018, vol. 63, no. 2, pp. 370-408.

McClelland P.L., Liang X., Barker V.L., CEO commitment to the status quo: Replication and extension using content analysis, "Journal of Management" 2010, vol. 36, no. 5, pp. 1251-1277.

Nadkarni S., Chen J., Bridging yesterday, today, and tomorrow: CEO temporal focus, environmental dynamism, and rate of new product introduction, "Academy of Management Journal" 2014, vol. 57, no. 6, pp. 1810-1833. 
Niedbalski J., Komputerowe wspomaganie analizy danych jakościowych (CAQDAS) w projektowaniu i prowadzeniu badań, "Nauka i Szkolnictwo Wyższe" 2013, vol. 1/41, pp. 185-202.

Patelli L., Pedrini M., Is the Optimism in CEO's Letters to Shareholders Sincere? Impression Management Versus Communicative Action During the Economic Crisis, "Journal of Business Ethics" 2013, vol. 124, no. 1, pp. 19-34.

Peterson R.S., Smith D.B., Martorana P.V., Owens P.D., The impact of chief executive officer personality on top management team dynamics: One mechanism by which leadership affects organizational performance, "Journal of Applied Psychology" 2003, vol. 88, no. 5, pp. 795-808.

Rafaeli A., Ashtar S., Altman D., Digital Traces: New Data, Resources, and Tools for Psychological-Science Research, "Current Directions in Psychological Science" 2019, vol. 28, no. 6, pp. 560-566.

Szczepaniak K., Zastosowanie analizy treści w badaniach artykutów prasowych - refleksje metodologiczne, "Acta Universitatis Lodziensis. Folia Sociologica" 2012, vol. 42, pp. 83-112.

Szymczyk B., Żakowicz W., Stemplewska-Żakowicz K., Automatyczna analiza tekstu: polska adaptacja programu LIWC Jamesa Pennebakera, "Przegląd Psychologiczny” 2012, vol. 55, no. 2, pp. 195-209.

Tausczik Y.R., Pennebaker J.W., The Psychological Meaning of Words: LIWC and Computerized Text Analysis Methods, "Journal of Language and Social Psychology" 2010, vol. 29, no. 1, pp. 24-54.

Yan B., Aerts W., Thewissen J., The informativeness of impression management - financial analysts and rhetorical style of CEO letters, "Pacific Accounting Review" 2019, vol. 31, no. 3, pp. 462-496.

\section{Abstract}

The purpose of this paper is to present the potential of content analysis as a method to study the psychological traits of firms' core decision makers. Research shows that these traits play a fundamental role in shaping corporate strategy and performance. The paper is theoretical, explaining the essence, origin and advantages of the method, indicating the application examples in sociology with an emphasis on the increasingly frequent use in management studies. It also identifies various methodological approaches of collecting data from written communication, showing the possible ways for scientists to bypass accessibility limitations to primary sources. The analysis of results shows a high validity of linguistic techniques used for assessing the antecedent psychological traits of core decision makers.

Keywords: content analysis, methodology, psychological traits, CEO communication, shareholder letters 